\title{
SWOT ANALYSIS AS A STRATEGY TO IMPROVE COMPETITIVENESS IN SEFOPE (STATE SECRETARIAT OF PROFESSIONAL AND EMPLOYEE TRAINING TRAINING) IN TIMOR-LESTE (CASE STUDY: IN THE SPECIAL HRD PART "DELIVERY OF WORKERS TO SOUTH KOREA 2015-2018"
}

\author{
Dircia dos Santos Ricardo ${ }^{1}$, Hermien Tridayanti ${ }^{2}$, Muchammad Arif ${ }^{3}$
}

\begin{abstract}
dirciabosco211212@gmail.com ${ }^{1}$, hermien.tridayanti@narotama.ac.id ${ }^{2}$, muchamad.arif@ narotama.ac.id ${ }^{3}$ Departement of Management, Faculty Economic \& Business, Narotama University Indonesia, Jl. Arif Rahman Hakim No.51, Klampis Ngasem, Sukolilo, Surabaya, Jawa Timur 60117 1,2,3
\end{abstract}

\begin{abstract}
This study aims to analyze and evaluate using the SWOT Analysis Technique as a Strategy to Increase Competitiveness at SEFOPE (State Secretariat for Employment Professional Training Affairs) in Timor-Leste (Case Study: Part of the Special HRD "Delivery of Workers to South Korea 2015-2018"). This research is descriptive qualitative research. Population and sample researchers used the sampling method, respondents will be taken in this study, namely 6 important officials from the Top Manger Level employees of all employees. Data collection techniques used: Observation, documentation, interviews and questionnaires. In calculating the score used is a Likert scale with the provision of rating values and weights. The analysis used is: IFAS and EFAS techniques. The results of this study indicate that from the results of the research conducted, the SEFOPE Institution is in quadrant III namely the Defend quadrant it is mean that SEFOPE has its human resources work is not in accordance with the determination of performance.
\end{abstract}

Keywords: SWOT Analysis, Competitiveness, IFAS-EFAS.

\section{INTRODUCTION}

Secretária do Estado da Formação Profissional e Emprego abbreviated as SEFOPE or Secretariat for Professional Training and Employment Affairs, this is on Jalan Caicoli, Vera-Cruz, Dili, Timor-Leste. Secretária de Estado da Formação Profissional e Emprego or SEFOPE which is one of the Government Institutions that functions as an institution providing public services, especially in the field of employment.

The SEFOPE Institute certainly conducts training for professions in the community and has access to many job vacancies offered by foreign companies and domestic companies. To answer the request. The SEPFOPE institution is required to plan and carry out the application registration flow by the government through a recruitment system and selection process that has been written in the SEFOPE strategy system which will later be accounted for by Civil Servants in the Human Resource Management (HRD) or Human Resources work unit.

According to (Egedius 2014) interpreting recruitment as a series of activities used by companies to attract prospective employees who have the abilities and attitudes needed to help achieve the objectives of the problem.

Work Unit Employees Human resources at SEPFOPE carry out a recruitment system and selection process instead of existing theories and strategy systems namely; recruiting workers is not based on company qualifications but is based on familiarity, Favoritism, origin, influential groups and other people's suggestions due to Culture, declared by Timor-Leste Workers Abroad and job applicants through face-to-face interviews and Google doc.

According to a previous study called (Soares 2014) the results of his research state that overseas work has been carried out by the government since 2008. In the first phase, the Timor-Leste Government through SEPFOPE sent 50 workers to South Korea. In 2011 the South Korean Government requested 2,500 workers, but Timor Leste only offered 400 workers; in 2012, South Korea wanted the number of employees to reach 2,750 but Timor-Leste once again only released 500 workers. In 2013 the South Korean government demanded workers to jump to 3,500 people, but the number coming from the Government of Timor-Leste only reached 280 workers. The Government of Timor-Leste, South Korea also reduced the number of employees to 1,750. In 2014 
the number of 100 workers will be sent. The total number of workers sent by the Government of Timor-Leste did not match the amount requested by South Korea in 2011 to 2013, which should have reached 7,570 workers.

The following is an illustration chart of the total numbers of East Timorese workers' offers to South Korea and the total sending of Timor-Leste Workers from SEFOPE to South Korea with the following data (20082014):

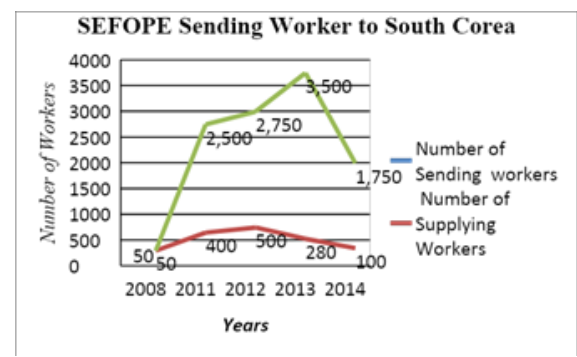

Source : http://sepfope.blogspot.com/2014/03/sepfope-sending-people-overseas.html .

Table. 1.1 SEFOPE Sending Worker to South Corea

\section{SWOT Analysis.}

According to (David Hunger J, Wheelen 1996) interpreting SWOT Analysis is an acronym for Strengths, Weaknesses, Opportunities and Threats from organizations, all of which are strategic factors or SWOT analysis must identify the company's distinctive competence namely certain skills and resources owned by a company and the superior ways they use.

\section{Competitiveness.}

According to (Jayanti 2011) competitiveness means strength, and competitiveness means achieving more than others or different from others in terms of quality, or have certain advantages.

\section{IFAS-EFAS.}

Strategic factors are the dominant factors of strengths, weaknesses, opportunities and threats that influence the conditions and situations that exist and provide benefits when positive actions are taken. (Nidyanurhasanah 2017).

\section{CONCEPTUAL FRAMEWORK}

The researcher has a provisional or hypothetical hypothesis on the problem of the researcher that:

1) Researchers want to know and identify weaknesses in the internal system of the SEPFOPE Institution by means of IFAS (Internal Strategic Factors Summary) analysis, which is to find out the analysis of various factors that affect the company's performance in achieving its success targets;

2) Not only internal problems that must be focused but, researchers also want that there is an external suspicion that will occur in SEPFOPE, namely the threat that comes from public trust in the potential of the SEPFOPE Institution in its service system directly or from other government institutions. And how to find out through EFAS Analysis (External Strategic Factors Summary;

3) The SWOT analysis strategy can improve competitiveness in SEFOPE.

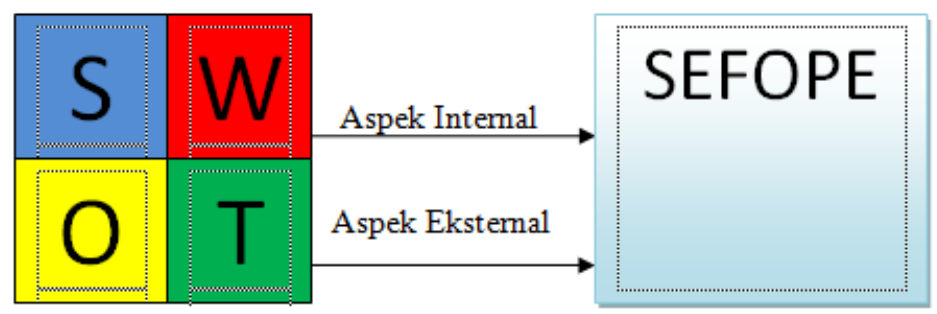

Figure: 2.1 Framework Model Thinks from this Researcher. Source: Author 2019 


\section{METHODOLOGY}

This type of research is descriptive qualitative. The researcher chose the object of research to implement the SWOT Analysis on SEPFOPE (State Secretariat for Training and Employment Professionals) on J1. Caicoli, Vera-Cruz, Dili, Timor-Leste. The population in this study were executive members, namely: six (6) people and researchers using the snowball sampling method. data sources, namely: premier data and secondary data. choose the technique of taking observation data, documentation, interviews and questionnaires. Research Instrument Design is the researcher himself and questionnaire. Data Analysis Techniques are IFAS and EFAS.

\section{RESULTS AND DISCUSSION}

SWOT Matrix (Strengths, weaknesses, opportunities, Threats)

\begin{tabular}{|c|c|c|}
\hline EFAS & $\begin{array}{l}\text { Strength (Strengths-S) } \\
\text { a.CentralService Government; } \\
\text { b.Prepare draft regulations for the } \\
\text { field of skills development and } \\
\text { employment services; } \\
\text { c. Deployment of East Timorese } \\
\text { people abroad as selling workers; } \\
\text { d. Has a strategic location. }\end{array}$ & $\begin{array}{l}\text { Weaknesses (Weaknesses-W) } \\
\text { a. Do not have branches that } \\
\text { many workers go to South } \\
\text { Korea; } \\
\text { b. Bad strategy system } \\
\text { c. Service that is not good d. } \\
\text { Determination of training that is } \\
\text { less balanced. f. Not answering } \\
\text { the applicant's step needs }\end{array}$ \\
\hline $\begin{array}{l}\text { Opportunities-O } \\
\text { a. Market Potential } \\
\text { b. Increase Promotion c. } \\
\text { Have Cooperation with } \\
\text { the Company } \\
\text { d. Relations with the } \\
\text { Government of South } \\
\text { Korea }\end{array}$ & $\begin{array}{l}\text { SO strategy } \\
\text { a. SEFOPE has the opportunity to } \\
\text { expand good market potential; b. } \\
\text { Increase Promotion; } \\
\text { c. Good relations are established } \\
\text { between the management of the } \\
\text { SEFOPE Institution and the } \\
\text { Bilateral Countries }\end{array}$ & \begin{tabular}{l}
\multicolumn{1}{c}{ WO Strategy } \\
a. Increase Market Potential; b. \\
Rebuilding the trust of foreign \\
companies towards Timor-Leste \\
HR; \\
c. Increase branches in various \\
districts; strati system, service \\
system \\
d. Increase appropriate training \\
determination \\
e. Increase focus on output and \\
provide a means for outcomes.
\end{tabular} \\
\hline $\begin{array}{l}\text { Threat (threats-T) } \\
\text { a. Competitor Strategy; } \\
\text { b. Worker Quality }\end{array}$ & $\begin{array}{l}\text { ST strategy } \\
\text { a. Improve strategies that become } \\
\text { competitive advantages; b. Improve } \\
\text { the quality of workers }\end{array}$ & $\begin{array}{l}\quad \text { WT Strategy } \\
\text { a. Increase competitive } \\
\text { marketing strategies; } \\
\text { b. increase the qualifications of } \\
\text { workers }\end{array}$ \\
\hline
\end{tabular}

Source Rangkuti 2016

Table 4.2 SEFOPE Matrix SWOT

\section{Internal environment analysis uses the IFAS table (Internal Factors Analysis Summary)}

\begin{tabular}{|l|c|c|c|}
\hline Internal key factor & Weight & Rating & Weight X Rating \\
\hline Strengths: & & & \\
\hline $\begin{array}{l}\text { a.Government Service Center } \\
\text { b. Prepare a draft regulation for the field of skills }\end{array}$ & 0,1 & 5 & 0,5 \\
development and employment services & 5 & 0,5 \\
$\begin{array}{l}\text { c.Prepare draft regulations for the field of skills } \\
\text { development and employment services }\end{array}$ & 0,1 & 5 & 0,5 \\
$\begin{array}{l}\text { d. Has a strategic location } \\
\text { Total Strength Score }\end{array}$ & 0,1 & 5 & 0,5 \\
$\begin{array}{l}\text { Weakness: } \\
\text { a. Do not have branches that many workers go to }\end{array}$ & 0,01 & 1 & $\mathbf{1 , 6}$ \\
$\begin{array}{l}\text { South Korea; } \\
\text { b. Bad strategy system }\end{array}$ & 0,145 & 4 & 0,01 \\
c. Not good service & 0,01 & 1 & 0,58 \\
& & & 0,01
\end{tabular}




\begin{tabular}{|l|c|c|c|} 
d. Determination of training that is less balanced & 0,145 & 4 & 0,58 \\
e. Less focus on an output and outcome by a & 0,145 & 4 & 0,58 \\
program. & & & \\
f. Not answering the applicant's step needs & 0,145 & 4 & 0,58 \\
Total score for Weakness & $\mathbf{0 , 6}$ & & $\mathbf{2 , 3 3}$ \\
Total internal factor scores & & $\mathbf{3 , 9 3}$ \\
\hline
\end{tabular}

Source: The results of the researchers were processed by the author on 4 July 2019

Table 4.3 IFAS Matrix

\section{External environment analysis uses the IFAS table (Internal Factors Analysis Summary)}

\begin{tabular}{|l|c|c|c|}
\hline External key factor: & Weight & Rating & $\begin{array}{c}\text { Weight X } \\
\text { Rating }\end{array}$ \\
\hline Opportunity: & & & \\
\hline a. Market potential & 0,1 & 3 & 0,3 \\
b. Increase Promotion & 0,1 & 3 & 0,3 \\
c. Have Cooperation with the Company & 0,15 & 3 & 0,45 \\
d. Relations with the Government of South Korea & 0,1 & 3 & 0,3 \\
Total Opportunity Score & 0,45 & & 1,35 \\
Threat: & & & \\
a. Competitor Strategy & 0,275 & 4 & 1,1 \\
b. Worker Quality & 0,275 & 4 & 1,1 \\
\hline \multicolumn{1}{|c|}{ Threat total score } & & & \\
\hline \multicolumn{1}{|c|}{ Total score of external factors } & $\mathbf{1 , 0 0}$ & & $\mathbf{3 , 5 5}$ \\
\hline
\end{tabular}

Source: The results of the researchers were processed by the author on 4 July 2019

Table 4.4 EFAS Matrix

Combination of Quantitative Strategies in Government Institutions especially in the field of employment and SEFOPE professional training

\begin{tabular}{|c|c|c|}
\hline EFAS IFAS & Strengths-S & Weaknesses-W \\
\hline Opportunity-O & $1,6+1,35=2,95$ & $2,33+1,35=3,68$ \\
Threats-T & $1,6+2,2=3,8$ & $2,33+2,2=4,53$ \\
\hline
\end{tabular}

Source: The results of the researchers were processed by the author on 4 July 2019

Table 4.5 Combinati 


\section{SEFOPE SWOT diagram}

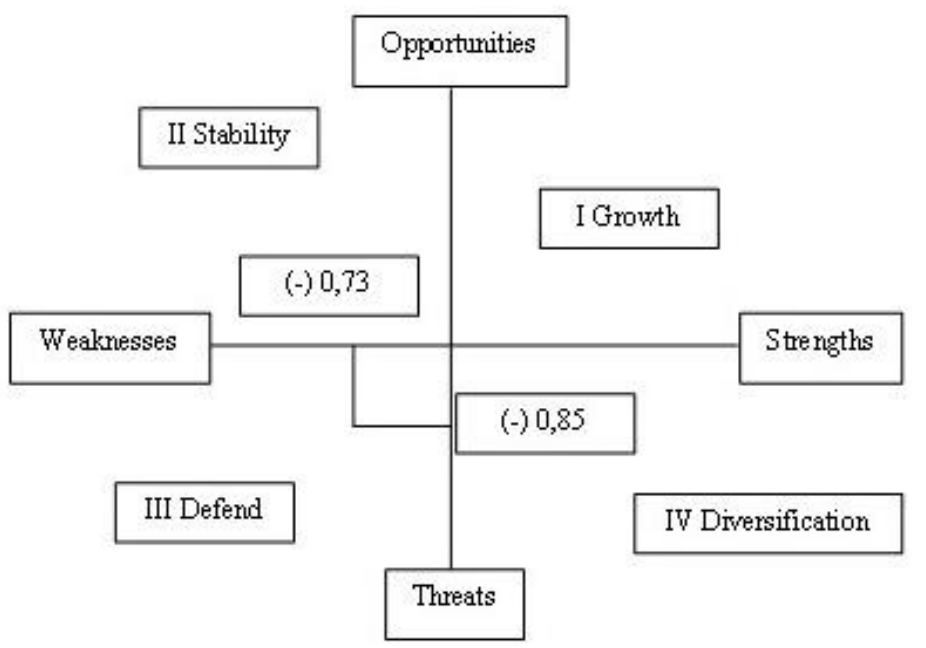

Source: The results of the researchers were processed by the author on 4 July 2019

Figure :4.1 SEFOPE Diagram

\section{CONCLUSION}

Based on the research carried out in the external environment as well as internally at the Government Institutions managing employment in Timor-Leste, SEFOPE, the results of the SWOT analysis included strength in the form of a central service government, preparing a draft regulation for skills development, location strategic and employment services, carried out sending East Timorese abroad as selling workers and having a strategic location, Weakness in the form of a lack of workers who work in accordance with authority and responsibility as professionalism, almost total quality management deteriorates so that there is injustice in the recruitment of workers, Opportunity factors in the form of holding rights as a channel for workers to go abroad, and also overcoming violations of labor law in Timor-Leste and abroad if there is official legal shipments from the SEFOPE Institute.

The last factor is the Threat factor in the form of the high competitiveness of various countries to be able to collaborate bilaterally with South Korea and other foreign countries using strategies that are always innovative and creative and hope to overcome this problem well. From the results of the research conducted, the SEFOPE Institution is in quadrant III namely the Defend quadrant which is also referred to as the WT strategy that uses its weaknesses to overcome all existing threats, so it can be concluded that the appropriate strategy to be implemented by the SEFOPE Institution is (1 ) improving the quality of human resources in order to compete abroad by using training facilities from the government professional certification institute Namely Centro Formação professionals e Emprego de Tibar (2) conducting job evaluations and performance to find out the results of the scale of income of these programs; (3) Make changes to the strategy in the formulation of strategies and implement strategies and also evaluate the strategies adopted by all parties.

\section{REFERENCE}

David Hunger J, Wheelen, Thomas L. 1996. Manajemen Strategis. Edited by Julianto Agung. 5th ed. Yogyakarta: ANDI.

Egedius, Vandeim. 2014. "Sistem Perekrutan Tenaga Kerja.” Blog Web. 2014.

https://vandemegedius.blogspot.com/2014/12/sistem-perekrutan-tenaga-kerja.html.

Jayanti, Dewi. 2011. "SKRIPSI ANALISIS SWOT SEBAGAI STRATEGI MENINGKATKAN DAYA SAING PADA HOTEL CHERRY PINK KH.WAHID HASYIM,” 18.

https://www.academia.edu/30437216/SKRIPSI_ANALISIS_SWOT_SEBAGAI_STRATEGI_MENINGK 
ATKAN_DAYA_SAING_PADA_HOTEL_CHERRY_PINK_KH.WAHID_HASYIM.

Nidyanurhasanah. 2017. “Analisis IFAS Dan EFAS.” 2017.

https://www.academia.edu/10041995/Tugas_management_strategis_2.

Soares, Brigida. 2014. "SEPFOPE: Sending People Overseas, Generating Money.” Webblog. 2014.

https://sepfope.blogspot.com/2014/03/sepfope-sending-people-overseas.html. 